\title{
Nadsat: The oscillation between reader immersion and repulsion
}

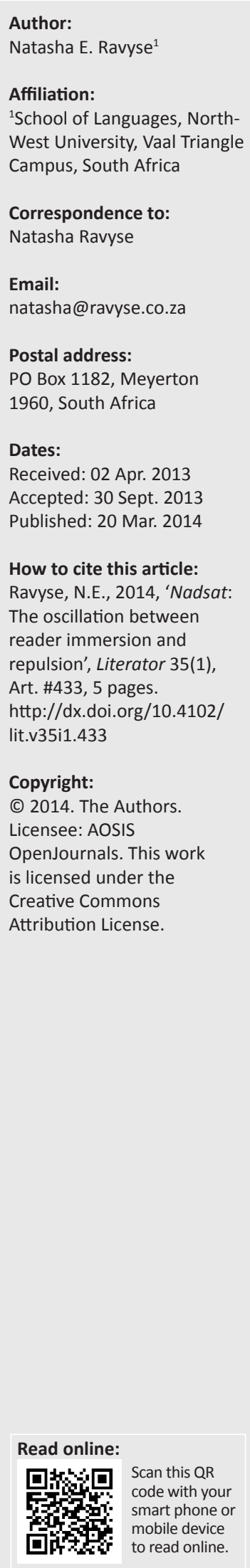

This article explores the oscillation between immersion and repulsion amongst readers of $A$ clockwork orange by Anthony Burgess. I argue that nadsat, as an invented language, introduces the state of 'reader immersion' resulting in 'flow' by means of a 'ludic reading' motivational structure. Reader curiosity acts as a 'positive reinforcer' through the sense of accomplishment felt by mastering nadsat. Reader repulsion occurs once nadsat is understood. Repulsion is induced as a result of the brutality the nadsat narrative communicates. However, repulsion does not necessarily cause the reader to stop reading, but rather acts as a sensationally derived motivation to continue reading. This type of motivation is identified as a 'negative reinforcer' . Both motivational structures (positive and negative reinforcers) develop the oscillation between reader immersion and repulsion as part of the reading experience $A$ clockwork orange offers. The aim of this article is to discuss the oscillation between immersion and repulsion experienced by readers of $A$ clockwork orange according to the theoretical frameworks indicated above.

Nadsat: Die ossilasie van leserbetrokkenheid en -afkeer. Hierdie artikel ondersoek die ossilasie tussen leserbetrokkenheid en -afkeer by die lees van A clockwork orange deur Anthony Burgess. Ek voer aan dat nadsat as doelgemaakte taal tot 'n toestand van leserbetrokkenheid lei, wat deur middel van 'n motiveringstruktuur van lees-vir-plesier 'vloei' in die leesproses bewerkstellig. Lesernuuskierigheid versterk die gevoel van vervulling wat die bemeestering van nadsat meebring, positief. Leserafkeer vind plaas met die verstaan van nadsat. Afkeer word veroorsaak deur die wreedaardigheid wat deur die nadsat-narratief gekommunikeer word. Hierdie afkeer veroorsaak egter nie dat die leser ophou met lees nie, maar dien as sensasiebeluste motivering om aan te hou met lees. Hierdie soort motivering word as negatiewe versterking beskou. Beide motiveringstrukture (positiewe en negatiewe versterkers) veroorsaak die ossilasie tussen leserbetrokkenheid en -afkeer as deel van die leeservaring wat $A$ clockwork orange bied. Die doel van hierdie artikel is om die ossilasie tussen leserbetrokkenheid en -afkeer te verduidelik volgens die teoretiese raamwerke wat hierbo aangedui is.

\section{Introduction}

According to Blake Morrison in the introduction of the 1996 Penguin edition of A clockwork orange, nadsat is a transliteration of Russian with many words originating from Slavic languages mixed in with a range of Cockney colloquialisms. Nadsat induces in the reader of A clockwork orange 'immersion' resulting in a state of 'flow' (Csikszentmihalyi 1990). It should be noted that the 'reader' referred to in this article is an amalgamation of the author's experience and other readers' reviews of $A$ clockwork orange, which were analysed in a previous study (Ravyse 2012). Immersion, as the product of 'ludic reading', and its motivational structure (Nell 1988), is an effect of how readers experience nadsat as the medium of narration. Nadsat as a gateway to immersion thus plays a significant role. The initial strangeness of nadsat induces immersion as reader curiosity is piqued. Readers experience a sense of accomplishment when they have deciphered nadsat, and on this pleasurable basis keep reading. Should certain readers make a 'stop reading decision' (Nell 1988:9), the immersive effect is not achieved and no oscillation occurs. However, this article postulates that readers who overcome the 'stop reading decision' allow the oscillation between immersion and repulsion to be a notable reading experience offered by the novel. The initial strangeness of nadsat, which prompts reader curiosity, and the sense of accomplishment the reader gains on understanding nadsat, forms a part of the 'motivational structure' 'ludic reading' emphasises. A 'motivational structure', in this case, stems from any intrinsic or extrinsic motivation a reader experiences in order to continue reading; it may be classified as a 'positive reinforcer' (Nell 1988). However, once the reader has mastered nadsat, the brutal connotations of the words become clear, and the reader now experiences the intensity of the narration and the 
violence it communicates. The reader is no longer protected by the initial buffer of not fully understanding nadsat; thus the desire to master it - as an intrinsic motivation and immersion would dictate - results in repulsion. However, the revealed brutality does not guarantee that the reader will stop reading. Brutality has a certain shock value and may act as sensationalistic motivation - or a 'negative reinforcer' - to make the reader continue reading. Thus, a continuous oscillation between immersion and repulsion is part of the reading experience $A$ clockwork orange offers.

Ludic reading theory, and immersion and flow theory as analytical tools, elucidate the reading experience which results from nadsat used in A clockwork orange. The resulting oscillation between immersion and repulsion is explained in the following sections.

\section{Theoretical exposition}

'Ludic reading' (Nell 1988:7) helps to explain the effect nadsat has on the reader of $A$ clockwork orange. The unfamiliarity of nadsat serves as a basis for interaction between the reader and the narrative as the curious reader is motivated to keep trying to understand nadsat. Such curiosity qualifies as what Nell (1988) calls a 'positive reinforcer'. A 'positive reinforcer' is an element expressed in the text which appeals to the reader and is associated with pleasant connotations. Thus the reader enjoys the content and immerses him- or herself in it.

A 'negative reinforcer' is an element within the text which has negative connotations for the reader. In such cases where they appear, the reader may make a 'stop reading decision' (Nell 1988:9). If the reader is significantly repulsed by what is narrated in nadsat, this could cause a 'stop reading' reaction. It is possible, however, for repulsive content to induce further reading. The effect is similar to that of the attraction afforded by sensational, macabre stories in the mass media. In fact, according to the research of Carver and Scheier (1981:38), one of the principal effects of 'ludic reading' is to master and gain control over salient emotions such as fear and disgust so that 'the reader experiences the goose-flesh of fear but not terror' (Nell 1988:43). It is possible for both positive and negative reinforcers to act as motivational principles to continue reading, and both seem to apply to nadsat. The effect on the reader would be conflictual. The reader initially immersed in a text, may then experience a negative reinforcer such as fear or disgust. However, the mechanism involved in ludic reading allows the reader to remain immersed regardless of the extent to which he or she finds the text repulsive. The immersion of a reader in a work is influenced by three main factors.

First is a heightened sense of reality of the attentional object (in this case, the attentional object is A clockwork orange); the second is that the full commitment of attention renders the subject impervious to distraction; and the third is that the vivid subjective reality experienced during episodes of absorbed attention has the effect of transfiguring both the observer and the attentional object, which acquires an importance and intimacy normally reserved for the self (Nell 1988:40).

The extent to which a reader is immersed influences the decision of the reader whether to continue reading or not. This decision is influenced by various factors, one of which is that a 'stop reading decision' may occur if negative reinforcers are foregrounded. However, this is not always the case because curiosity, for example, may motivate the reader to continue reading regardless of the experience - as previously explained. This is because the reader relation is manifested in the reading experience, but the emotion is dulled or controlled by the conscious mind. Repulsion in the present case is governed by two elements: the negative element and the unfamiliarity of expression. Any type of repulsive element may provide motivation to continue reading because it has shock value. The unfamiliarity of nadsat and what the narrative communicates - which also results in repulsion motivates the curious reader to keep reading. The curiosity provoked by an unfamiliar context, regardless of the degree of repulsion, curbs the reader's 'stop reading decision'. Both the attractive and repulsive elements in A clockwork orange related to ludic reading result in immersion, so setting up the oscillation between the two.

Mihaly Csikszentmihalyi developed the theory of 'flow' in 1990 in an attempt to account for the immersive state individuals experience when engaged in certain activities. 'Flow' is the mental operation in which individuals feel immersed in experiences of focus, involvement and enjoyment during an activity. This state is autotelic, or 'engaged in for its own sake' (Hornby 2005:86). From this definition it is clear that the experience of flow is intrinsically rather than extrinsically motivated. Intrinsic motivation in the context of reading is important as it contributes to the reader's experience of the text. More specifically, the immersive experience caused by ludic reading results in the state of flow which informs the autotelic experience of readers. The link between immersion and flow is influenced by the experience and reaction of the reader. The reader is immersed in the text whilst reading. This immersive experience is then heightened into a state of flow. This state of flow is reached by means of ludic reading and serves to help explain the motivational structure of reading and the rewards it offers. A clockwork orange offers the reward of mastering an unfamiliar language. Mastery of this new language allows for the immersion and repulsion oscillation to gain significance. After mastering nadsat through an immersive experience of flow, the reader starts to realise the unpleasant nature of the events communicated at a deeper level of understanding rather than that experienced at the beginning of the novel. After the initial sense of accomplishment, the reader experiences repulsion.

\section{Application Immersion and flow}

Nadsat is an invented language which Burgess uses as a tool to underscore the idea of brainwashing. This is significant as the effect of learning nadsat goes beyond superficial 
understanding. Burgess (1990) explains his reasons for using nadsat as follows:

As the book was about brainwashing, it was appropriate that the text itself should be a brainwashing device. The reader would be brainwashed into learning minimal Russian. The novel was to be an exercise in linguistic programming, with the exoticisms gradually clarified by context: I would resist to the limit any publisher's demand that a glossary be provided. A glossary would disrupt the programming and nullify the brainwashing. (p. 7)

Burgess's explicit resistance to the publication of a glossary ensured that the learning process surrounding nadsat would form an integral part of the reading process. Although nadsat is initially strange to the reader, it does not take long to understand what is being communicated. The dust jacket of the Heinemann edition of A clockwork orange (1962) promises that it will take the reader no more than fifteen pages to master and revel in the expressive language that is nadsat' (see Evans 1971:406). Though this might be true, a certain level of dedication is required in order to make sense of the narration. The following extract - from within the first fifteen pages - demonstrates the complexity of nadsat, and how reader dedication is required in order to register meaning:

Pete keeping chasso without, not that there was anything to worry about out there. As soon as we launched on the shop we went for Slouse who ran it, a big portwine jelly of a veck who viddied at once what was coming and made straight for the inside where the telephone was and perhaps his well-oiled pooshka, complete with six dirty rounds. Dim was round that counter skorry as a bird, sending packets of snoutie flying and cracking over a big cut-out showing a sharp with all her zoobies going flash at the customers and her groodies near hanging out to advertise some new brand of cancers. What you could viddy then was a sort of a big ball rolling into the inside of the shop behind the curtain, this being old Dim and Slouse sort of locked in a death struggle. Then you could sloshy panting and snoring and kicking behind the curtain and veshches falling over and swearing and then glass going smash smash smash. Mother Slouse, the wife, was sort of froze behind the counter. We could tell she would creech murder given one chance, so I was round that counter very skorry and had a hold of her, and a horrorshow big lump she was too, all nuking of scent and with flipflop big bobbing groodies on her. I'd got my rooker round her rot to stop her belting out death and destruction to the four winds of heaven, but this lady doggie gave me a large foul big bite on it and it was that did the creeching, and then she opened up beautiful with a flip yell for the millicents. Well, she had to be tolchocked proper with one of the weights for the scales, and then fair tap with a crowbar they had for opening cases, and that brought the red out like an old friend. (Burgess 1996:10; author's italics)

The above extract might be termed 'sensational' in a popular media sense - taking into account the connotations this term has regarding readers' interest. Also, as Alex feels no regret or remorse, the reader is intrigued. The nadsat words - typed in italics - do not yet have a clear meaning, and thus also intrigue the reader. The strangeness of the words motivate the reader to want to understand them. Judging from my own reading experience, I concur with Nixon (2009) when he explains that: the unfamiliarity of words used may cause the reader to subconsciously view Alex [and the content of his narration in nadsat] as having some kind of unfathomable knowledge in an esoteric field. (p. 7)

The reader thus deems nadsat worthy of mastery because of the potentially special or esoteric knowledge it may communicate. When readers have mastered nadsat, the state of flow is heightened and this motivates them to continue.

\section{Repulsion}

Repulsion in A clockwork orange is the result of a gradual process which is largely dependent on the learning of nadsat. The uninitiated reader is confronted with a riddle-like narration of events:

They had no license for selling liquor, but there was no law yet against prodding some of the new veshches which they used to put in the old moloko, so you could peet it with vellocet or synthemesc or drencrom or one or two other veshches which would give you a nice quiet horrors how fifteen minutes admiring Bog And All His Holy Angels and Saints in your left shoe with lights bursting all over your mozg. Or you could peet milk with knives in it, as we used to say, and this would sharpen you up and make you ready for a bit of dirty twenty-to-one, and this is what we were peeting this evening I'm starting off the story with. (Burgess 1996:3)

Without understanding nadsat, the reader is able to grasp the content, yet, the reader will not be able to experience the virtual brainwashing Burgess intends, which implicates the reader in the novel's theme of immorality. It is nadsat, indeed, which triggers a set of processes resulting in an oscillation between immersion and repulsion. As stated, it is important to note that the unfamiliarity of nadsat may make it seem not only strange, but repulsive too, because it is close to incomprehensible for the uninitiated reader. And as the reader reflects on what the passage is about, it becomes clear that Alex speaks of drug abuse and of the unsavoury actions he intends to carry out later, repulsive to most readers, but also attractive because sensational, and so a guarantor of continual reading. Additionally, readers will not want to compromise their achievement in mastering nadsat by not finishing the novel.

Complexity concerning the readers' immersion and repulsion oscillation is presented once nadsat has been mastered, because the brutal connotations of nadsat words and actions described are now understood by the reader. The protective veil of incomprehension has been lifted. As Burgess explains, 'to tolchock a chelloveck in the kishkas does not sound as bad as booting a man in the guts' (Burgess 1996:xviii).

\section{Oscillation between reader immersion and repulsion}

To demonstrate the oscillation between immersion and repulsion in the development of the reading experience, an extract from after the first fifteen pages of $A$ clockwork orange is provided; it reads as follows: 
I was howling too and like yawing but I banged my gulliver smack on the hall-wall, my glazzies being tight shut and the juice astream from them, very agonizing. So there I was like groping the hallway as the millicents arrived. I couldn't viddy them, ofcourse, but I could sloshy and damn near smell to von of the bastards, and soon I could feel the bastards as they got rough and did the old twist-arm act, carrying me out. I could also sloshy one millicent golos saying from like the room I'd come out of with all the kots and koshkas in it: 'She's been nastily knocked but she's breathing,' and there was a loud mewing all the time. 'A real pleasure this is,' I heard another millicent golos say as I was tolchocked very rough and skorry into the auto. 'Little Alex all to our own selves.' I creeched out: 'I'm blind, Bog bust and bleed you, you grahzny bastards.' 'Language, language,' like smecked a golos, and then I got a like backhand tolchock with some ringy rooker or other full on the rot. (Burgess 1996:49)

Even without the reader's understanding of nadsat, the passage conveys a great deal of violence, but by now, after forty-nine pages, he or she becomes fully aware of its extent. Despite this fact, the reader, intrigued, is drawn into the story. Perhaps repulsed by the behaviour and crudity, the reader is yet immersed in the situational context because of developed comprehension of nadsat. The reading experience shifts from immersion to repulsion, and oscillates between the two.

\section{The limitation of reader repulsion}

The complexity surrounding the limitations of reader immersion and repulsion is evident in the reviews written on A clockwork orange. Some reviewers show appreciation for the novel. For example, Calvert (2002) is of the opinion that:

A Clockwork Orange is a book that could be enjoyed by any reader and perhaps even contains a few social lessons that we could all learn from. Like a lot of books, though, it is only as deep as the reader wants to look and at any level it is an enjoyable read. (p. 3)

Edwards (2007), shares Calvert's (2002) sentiment, stating that:

A Clockwork Orange is an icon in genre fiction, and the source material for Stanley Kubrick's controversial film. Any speculative fiction fan who hasn't read the novel (if such a person exists) should do so immediately. (p. 2)

In addition, Tanguay (1996:3) writes that, 'this is a real horrorshow book.'

Some reviewers are not so keen: for example, Richards (2011) writes,

A Clockwork Orange is frightening and unpleasant. It explores the centuries-old debate on free will versus determinism. Although I am grateful for reading the book, I find it difficult to recommend. (p. 1)

Geddes (1999) is of the opinion that the book is:

an enjoyable work, but somewhat light, and not really masterful. The structure and the philosophy are just too easy. Work has gone into the smoothness of the prose, and the transitions, which are never jarring. Philosophically, I appreciated the fact that Alex's indoctrination took the form of movies. It was like the theatre scene in Hamlet, and had echoes of the Allegory of the Cave. As such, Burgess shows himself to be an interesting novelist of ideas, but not profound. (p. 2)

Harris (2008:2), asserts that 'Burgess' ability to see Alex's crimes as just a distasteful minor circumstance is frankly disgusting.' It is true that some of the behaviour in the novel is distasteful, but the detailed accounts of this distasteful behaviour, in my opinion, perform a very important function as part of the moral complexity thematically communicated in the novel.

Despite the mixed reviews, $A$ clockwork orange is a widely read piece of fiction. It is interesting to notice that regardless of the positive or negative nature of the reviews, all seem to present a common foundation formulating a reading experience. The reviewers that have read the novel all base their opinion of A clockwork orange on their experiences of immersion and repulsion. The positive reaction of Calvert (2002) supports Nixon's (2009) explanation of esoteric or special knowledge communicated in the novel by stating that $A$ clockwork orange contains social lessons. The attraction of these lessons contributes to the immersive effect as it appeals to the greater human quest for meaning on a deeper philosophical level. Moral choice, as a prominent theme of $A$ clockwork orange, is then propagated through the reading experience of some readers. Conversely, Richards (2011) described the book as unpleasant and frightening. Such a reaction to the narrative may illustrate a superficial interpretation which leaves the reader unable to grasp a deeper meaning. This inability may be propelled by repulsion experienced by the reader. Just as the readers may experience dual interpretations and as a result, dual reading experiences, the moral choice of humanity as a theme illustrates the duality of the moral person. The oscillation between reader immersion and repulsion is conducive to highlighting the morality and immorality of mainstream society.

The duality of this moral choice encouraged by the oscillating reading experience is shown by examining some key extracts from A clockwork orange. Alex describes the blood he and his droogs draw as 'beautiful' (Burgess 1996:7), demonstrating his pleasure in other people's pain. His lack of empathy has an unsettling effect on the reader. He seems to be innately evil. His 'Post Corrective Adviser' (Burgess 1996:29), corroborates this view, although he also points out the choices open to Alex, because of his innate capabilities and his upbringing: 'You've got a good home here, good loving parents. You've got not too bad of a brain! Is it some devil that crawls inside of you?' (Burgess 1996:30). Choice, for Burgess (1996) is important:

A human being is endowed with free will. He can use this to choose between good and evil [...]. It is as inhumane to be totally good as it is to be totally evil. The important thing is moral choice. (p. viii)

Thematically, choice is an important concept in A clockwork orange, and it is not limited to the message Burgess advocates. As a limitation of the oscillation between reader immersion and repulsion, nadsat, to the uninitiated reader, acts as a buffer protecting the reader from Alex's brutal behaviour. 
However, Alex's brutality is not censored for long as the reader eventually understands nadsat. The censored or buffer effect that the initial incomprehension of nadsat has, may be maintained by the reader in order to downplay the brutality communicated in nadsat. The brutality, nevertheless, cannot be totally ignored no matter the effort on the readers' behalf. As a result, it is possible that the reader may have ambivalent feelings towards Alex because of the repulsion felt towards his actions and then the feeling of sympathy when Alex's humanity is taken from him.

The emotional ambivalence becomes evident whilst Alex is imprisoned as he accounts for his experience, using nadsat. No other inmates speak nadsat and yet Alex still expresses himself in this language because the only individual that can understand him at this point is the reader. By doing so, Alex has imposed a sense of a 'brotherhood' unto the readers. A feeling of isolation and loneliness is felt by Alex and by association, the reader, exposing vulnerability in both participants. An intimacy is therefore established between Alex and the reader, promoting reader sympathy. Reader sympathy then, may act as a disarming mechanism for the repulsive element - demonstrating its limitation - rendering the oscillation obsolete.

\section{Conclusion}

In conclusion, the attempt to master nadsat results in immersion, and flow is established. Ludic reading propagates immersion and flow as the process of learning nadsat is motivated by the strangeness and curiosity created by the narrative. This motivation acts as a positive reinforcer as the reader aims to master nadsat so that a sense of accomplishment may be experienced by doing so. Even though nadsat is initially strange, the reader is eventually able to infer meaning. The interim period between learning and understanding nadsat acts as a buffer or a veil which is eventually lifted, exposing the brutality in the nadsat narrative. This marks the beginning of the oscillation between reader immersion and repulsion as the readers - as a result of the brutality and crudity - are repulsed by what had initially immersed them in the text. However, reader repulsion does not necessitate a decision to stop reading. Sensationalistic motivation acts as a negative reinforcer of which the result is continued reading. In addition to sensationalistic motivation, the reader has invested in mastering nadsat and in finishing the novel. Repulsion, then, is not enough to deter readers, and in fact motivate reading. Oscillation between reader immersion and repulsion in A clockwork orange, results from the curiousness of the nadsat narrative, the mastery of nadsat, and eventually the brutal sensationalism of the narrative. The reader maintains motivation, whether it be the outcome of a positive or negative reinforcer - or both - in order to finish the novel. This oscillation is representative of the reading experience $A$ clockwork orange offers demonstrating an indefinite decision regarding immersion and repulsion. The oscillation between immersion and repulsion is further problematised through the readers' sympathy felt towards Alex resulting in the limitation of the repulsive effect. Reader sympathy may override reader repulsion towards the end of the novel, but reader sympathy can only act as a limitation of repulsion if repulsion was part of the initial reading experience coupled with immersion. Reader immersion remains constant throughout the novel and it is reader repulsion and reader sympathy that create the dynamic for oscillation. The indecision of readers results in oscillation between reader immersion and repulsion, highlighting the importance of choice which is reflected in a statement made by the prison chaplain:

'It's not been used yet,' he said, 'not in this prison, 6655321. Himself has grave doubts about it. I must confess I share those doubts. The question is whether such a technique can really make a man good. Goodness comes from within, 6655321. Goodness is something chosen. When man cannot choose he ceases to be a man'. (Burgess 1996:63)

\section{Acknowledgements}

I would like to thank Dr A.C. Swanepoel for her guidance and support in conceiving and designing this article. Thank you to both Ms K. Redelinghuis and Mr J. Heyns for translating the abstract. To the anonymous reviewers who provided feedback for the first draft, thank you for your much-appreciated contributions. I would finally like to thank Professor Meihuizen and Professor Viljoen for their valuable input in the second revision.

\section{Competing interests}

The author declares that she has no financial or personal relationship(s) that may have inappropriately influenced her in writing this article.

\section{References}

Burgess, A., 1990, You've had your time, Heinemann, London.

Burgess, A., 1996, A clockwork orange, Penguin, London.

Calvert, S., 2002, Review of 'A clockwork orange' by Anthony Burgess', Book Reviews, viewed 10 June 2012, from http://www.steve-calvert.co.uk/book-reviews/aclockwork-orange.htm

Carver, C.S. \& Scheier, M.F., 1981, Attention and self-regulation: A control theory approach to human behaviour, Springer, New York. http://dx.doi.org/10.1007/9781-4612-5887-2, PMCid:PMC1401745

Csikszentmihalyi, M., 1990, Flow: The psychology of optimal experience, Harper and Row, New York.

Edwards, J., 2007, Review of 'A clockwork orange' by Anthony Burgess', Science Fiction Reader, viewed 10 June 2012, from http://sfreader.com/read_review.asp?book=537

Evans, R., 1971, 'Nadsat: The Argot and its implications in Anthony Burgess' A clockwork orange', Journal of Modern Literature 1(3), 406-410.

Geddes, D., 1999, Review of 'A clockwork orange' by Anthony Burgess, The Satirist, viewed 10 June 2012, from http://www.thesatirist.com/books/ClockWorkOrange. html

Harris, S., 2008, 'The end of faith', Live Journal, viewed 10 June 2012, from http:// baeraad.livejournal.com/61218.html

Hornby, A.C., 2005, s.v. 'Autotelic', in S. Wehmeier, C. McIntoch, J. Turnbull \& M. Ashby (eds.), Oxford advanced learner's dictionary, 7th edn., Oxford University Press, Oxford, p. 86.

Morrison, B. 1996, 'Introduction', in A. Burgess, A clockwork orange, pp. vii-xxiv, Penguin, London.

Nell, V., 1988, 'The psychology of reading for pleasure: Needs and gratifications', Reading Research Quarterly 23(1), 6-50. http://dx.doi.org/10.2307/747903

Nixon, M., 2009, 'The use and effects of fictional argot in Anthony Burgess' A clockwork orange', Wordpress, viewed 14 March 2012, from http://zunfa.files.wordpress. com/2011/09/use-of-fictional-argot-in-a-clockwork-orange.pdf

Ravyse, N., 2012, 'A clockwork orange: The dynamics between reader identification and cultural frameworks', Honours mini-dissertation, Dept. of Languages, North-West University, Vaal Triangle Campus.

Richards, D., 2011, 'What fried chicken and shepherd's pie teach us about free will and determinism', in Goodreads, viewed 10 June 2012, from http://www.goodreads. com/review/show/170628462

Tanguay, E., 1996, Review of 'A clockwork orange by Anthony Burgess \#56', Fu-berlin, viewed 10 June 2012, from http://userpage.fu-berlin.de/ tanguay/book56.html 